\title{
Tronchin and Boerhaave
}

\author{
By G.A. LiNDEBOom
}

\section{Introduction}

In the years 1907 to 1909 the Dutch medico-historian A.GEYL wrote a few papers ${ }^{1,2}$ on the famous Swiss physician Theodore Tronchin (1709 to 1781), in which his portrait was painted with less favourable colours and traits than had been done before. Geyl's papers caused some surprise at the time. They even aroused some feeling in the Swiss, who were used to think a gooddeal more of their Tronchin. Dr REBER ${ }^{3}$ of Geneva even expressed the wish «que les récentes publications des Hollandais puissent s'atténuer un peu». As a matter of fact, after Geyl's death he was stated to have been sometimes a little aggressive.

It is by no means my intention again to enter into this matter: the appreciation of such a celebrated doctor as Tronchin undoubtedly was. On the contrary I want to make a conciliative gesture-if still necessary after half a century-by discussing the relation between Tronchin and Boerhaave, and publishing some hitherto unnoticed letters of his. Doing so I hope to make a small contribution towards the knowledge of Tronchin's life and personality. Theodore Tronchin was 19 years old, when he entered Leyden in 1728 to complete his medical studies; by that time BoerhaAve had reached the age of 60 , and he was at the summit of his renown. This experienced teacher and eminent judge of men must have immediately noticed among his pupils the young Swiss as being a promising, above average gifted student. Ambitious Tronchin will surely have liked personal acquaintance with Boerhaave, and he might have been searching for some occasion. So it was no wonder that connections were established that lasted for as long as Boerhaave lived. At that time already, but certainly later on, this connection, and in particular Boerhaave's opinion on Tronchin, has been represented in a biased and exaggerated way, e.g. by VAN DER AA ${ }^{4}$ and $\mathrm{JAY}^{5}$.

1 A.GeYL, Dr Theodore Tronchin, Sudhoffs Arch. Gesch. Med. (1908) p. 81 and 289.

2 A. Geyl, Geneesk. Courant 1907, p. 85 and 93.

3 M.B.Reber, Deux documents médits de Tronchin, Bull. Soc. franç. hist. Méd. 1909, p. 356.

4 VAN DER AA, Biografisch Woordenboek 1870, sub voce Tronchin.

${ }^{5}$ Frank Webster Jay, $A$ Letter and the Memories Associated with It, Chicago 1898. 


\section{Tronchin in Holland}

Theodore Tronchin was born on May 24, 1709, at Geneva, where his father was a banker. He got a solid classical education at the Town College in that city, after which he enrolled at the Academie as a student of theology in 1723. However, he was but little enthralled by this study, and the consequences of his father's bancruptcy in 1720 made him decide to go to England, where he had a remote relation, Lord BoLingBroke. There he entered on medical studies at Cambridge University. This occasioned his acquaintance with a book attributed to Boerhaave, which aroused his admiration. He decided to continue his studies at Leyden, and he went off after having walked the wards in London for some months. Probably the decission was the easier as he had some distant relations at Amsterdam, the Tronchins du Breuil ${ }^{6}$. Moreover, close relations were maintained between the two Protestant Republics of those days. And, owing to Boerhaave, the Leyden medical faculty was reputed to be the best of Europe.

So Tronchin was registered as a medical student at Leyden on September $13^{\text {th }}, 1728$. It seems that his tall figure, his keen appearance, and his luxuriant hair dress soon drew the attention of the famous professor. And, as the story goes, Boerhaave dropped a few words some day on such beautiful hair dress requiring a lot of time. Tronchin, being informed of this, had immediately his hair cut-a turn that pleased Boerhaave.

Tronchin studied succesfully. Already on August $22^{\text {nd }}, 1730$, he graduated on a thesis about the clitoris, De nympha. The fact was entered in the university records with the words ${ }^{7}$ :

1730. 22 Aug. Theodorus Tronchin: Genevensis, privatim disputavit de nympha, et a magnifice Rectore Boerhaavio medicinae doctor dictus est.

The thesis ends with a high-flown boutade on the role and the sense of the clitoris in the life of man-certainly very curious from the mouth of such a young person as Tronchin at that occasion was!

Four days after his graduation he was registered as citizen ("poorter") of Amsterdam, and, on production of his doctor's diploma and citizen papers, as practitioner on October the $31^{\text {st }}$ of the same year. Perhaps he chose Amsterdam on advice of his teacher. It seems there was sufficient opportunity. Tronchin wrote about Amsterdam: "Frequens erat morbus, rara medicina" in the preface of his De colica pictonum in 1757.

${ }^{6}$ H.Tronchin, Un médecin du $18^{e}$ siècle, Theodore Tronchin, Paris 1906, p. 7.

7 Kroon, Boerhaave as professor-promotor, Janus 23 (1918) 291. 
Van der $\mathrm{Aa}^{4}$ informs us about Tronchin in his Biographisch Woordenboek, 1876, that Boerhaave had a high opinion of him. Yet, Jay ${ }^{5}$ quotes Van der Aa in the wrong way, when he let him state "that when Tronchin graduated at Leyden in 1730, and was considering England as the country in which to practice, Boerhaave wrote a letter to some one in that country in which he said that those in England who desired to consult him could do so without traveling to Holland by consulting Tronchin at home". Actually Van der Aa wrote as follows: "During the time that Tronchin was preparing to set off for England, he (Boerhaave) took him to Amsterdam, and showed his beloved pupil to every one. 'He is my other self', he used to say, 'in future people can consult me without leaving Amsterdam'."

The first years of practice were not easy, of course, for the young Swiss physician in Amsterdam. Undoubtedly fact that he was one of Boerhaave's pupils was a strong moral support.

Boerhaave sympathized with his former pupils as much as possible, and so Theodore Tronchin may have shared his fatherly friendship. H.Tronchin gives in his biography of Theodore Tronchin, quoted above, some passages from two of Boerhaave's letters that clearly prove this. But in a letter of September 7 1732, published by H.Tronchin from the family records, Theodore declined the name of Boerhaave's friend.

«En me donnant le beau nom d'ami de M. Boerhaave, vous me donnez un titre où je n'ai gardre de prétendre. Je serais peu en état de le soutenir, puisque vraisemblement je serais peu en état de le mériter. Mes sentiments par rapport à lui font naître en moi l'admiration et le respect, et ceux qu'il peut avoir pour moi font tout au plus qu'il m'honore de sa protection et de ses conseils.»

But H.Tronchin quotes a letter from Van Swieten to Tronchin to contrast this expression of his modesty. There it runs «Boerhaave vous estime beaucoup plus que vous le croyez de votre modestie».

\section{Correspondence between Tronchin and Boerhaave}

As a matter of course it was very important to young Tronchin that he could ask Boerhaave's advice in difficult cases during his first years of practice for as long as Boerhaave was still alive. There are two hitherto unpublished letters of Tronchin's in which he asks Boerhaave's advice for one of his patients. The first is dated 1735 . 
Medicorum Sapientissimo, Hermanno Boërhaave, S.P.D.Theodorus Tronchin

Vir maturae aetatis; temperiei laxae, obesus, ante septennium tum et biennium, intermittentem putridam febrim; intacta materie cortici Peruviano sustulit. Illa Hypochondriis atque Mesenterio inhaesens, infarctionis, tensionis, ponderisque sensum, duram alvum, urinam rubicundiorem, crassiorem, turbidiorem, cruditatem putridam, halitum fortem, linguam sicciorem sordidam reliquit; In variis corporis locis carbunculos, herpetem in facie, dolores tandem colicos in plexibus nervorum intercostalium meseraeis saevissimos Pictonum dictos, fecit.

Per os, anum, cutim ingestis, applicatis, emollientibus, aperientibus, saponaceis, laxantibus, ex succis imprimis copiosis Mayalium antiscorbuticarum recentibus, soluta demum oleosa, putrefacta, acerrima materies, horripulationes strangurias, tenesmos, motus spirituum turbatos, lipothymias, ciborum fastidium; nunc vero per liquidissimam alvum excreta, virium dejectionem fecit.

Qua perterritus aeger, quid de se sentias, Vir Summe, avidus scire cupit; metuens ne diuturnior succorum usus nimium frangat vires, quem tamen superstes ad huc materies longiorem forte indicaret, nimirum ut depurata magis Viscera spadanis tutius committi queant. Qua de re si Tua habeatur sententia impavidus erit aeger, tutus erit Medicus. Amstelodami $17 \frac{20}{5} 35$.
The most wise of physicians, Herman Boerhaave, is greeted by Theodore Tronchin

A man of mature age and weak constitution, fat, suffered from an intermitting putrid fever seven years ago, and again two years ago, and without touching the (prescribed) medicines, he rid it with Peruvian bark. That fever, attached to the hypochondria and the mesentery, has left a sensation of constiveness, tension and heaviness, with hard stools, reddish, thick, turbid urine, heavy breathing, indigestion (dyspepsia) and a somewhat dry, coasted tongue. It has caused carbuncles in several places of the body, herpes in the face, and finally very serious, so-called Pictonian, colics in the plexi of the intercostal nerves.

At last, the application of mellowing, aperient, saponacious, expulsive medicines, consisting in particular of fresh juices of anti-scorbutic Mayalia, ingested by mouth, anus and skin dissolved an oily, putrid, sharp matter, difficulties with urination, tenesmi, confused movement of the spirits of life, attacks of fainting, aversion of food: But now he is losing strength by excretion of very thin stools.

Worried by this, the patient is anxious to know what you, superior man, think of it; for he fears that longer use of the juices will break his strength, too much, whilst still the remaining matter may indicate it. Of course, in order that the greatly purged entrails can more safely be entrusted to Spa water. If we know your opinion on this, the patient will be without fear, and the physician will be safe.

Amsterdam May 201735. 
Othedicorum Sapientisicmo, Hermanns Börtasue, S. $\mathcal{D} . \mathscr{D}$.

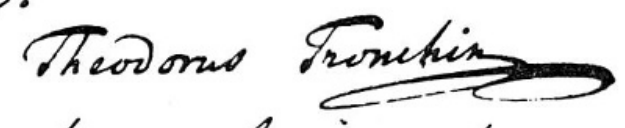

Vir satarce atatis, temperici laswes, obesni, ante supennium tim et bicnnium, intermittentem pusmox febrim, intacta miterie cortici biruvians burtilis. Ha. Hypochontrüs atgui hesenterio ishosens, infordionis,

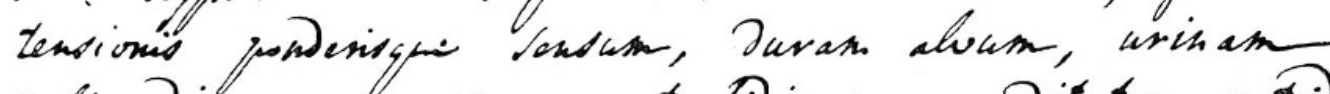

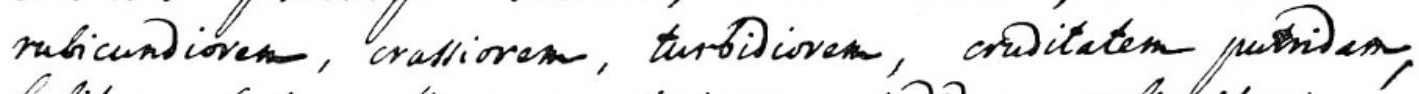
falituse fortem, linguan vicciovem forbilam seliguit; In varis conporis locis carbunculos, hirpeten is facie, Dolores tanden colicos in plexubus hervorum Intercostalisis. Sneserceis Savisionss bictonum gicts fecit.. ber os, as un, cutis ingestis, applicatis, esollientibus, quevientibus, Sapon aceis, Laxantibis, ex succis imprimid copiosis Mayalium antiscorbuticaring recentibus, Solute Pemin olessa, putrefacta, acerrima materies, horripulationes stranguvias, tenesmus, motud spinturen turbatos,

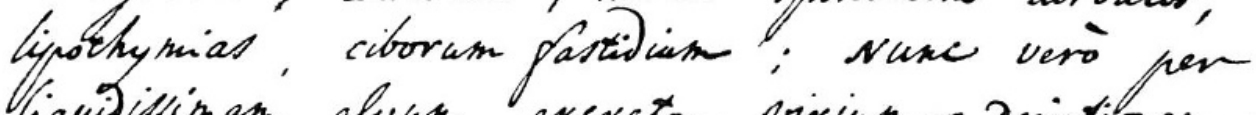
Ciquisisimam aluan exereta, viriut jyactionen feit. Imi perterritus ceger, quil de se Sentias, Virn Slamme, avilus Jire cupit, 'metuens he Diuturnior Succorum. Dos nimium fisngat esies, quem-tamen Supentes Dhue hateries conyiorem fortio inticaser, nimirin

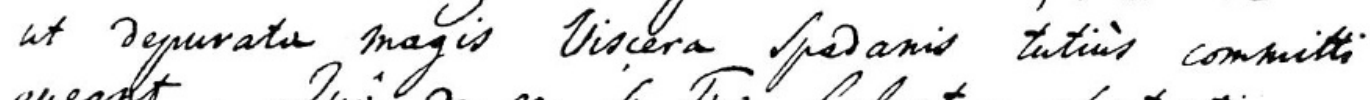

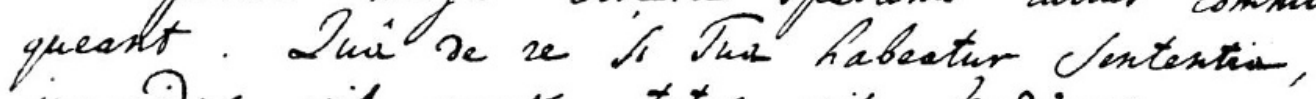
impavidur erit agere tutus onit hesicus. amstelodany $12 \frac{20}{5} 35$.

Figure 1. Letter from Tronchin to Boerhaave, dated May 20, 1735 
Boerhaave was used to answer very conscientiously such requests for advice, to which he often added detailed directions for manner of living and diet, and prescriptions. He somtetimes found this vast and time-wasting correspondence a burden, but he never withdrew from it.

Owing to a peculiar co-indicence one such letter with medical advice from Boerhaave to Tronchin is preserved. F. W. Jay, already quoted, tells us of his "presence one winter afternoon in the darkest corner of a secondhand book store, examining a row of dirty volumes, among which I came across a dilapidated copy of an English translation of Boerhaave's Aphorisms. Lying loosely between its pages I found an age-browned letter. It was addressed, Mijn Heere, den Heere, Theodorus Tronchin, beroemd geneesheer te Amsterdam."

It concerned a letter from Boerhaave to Tronchin.

As Jay's publication seems to be little known, owing to the fact that the title, A letter and the memories associated with it, does not contain the name neither of Boerhaave or of Tronchin, I will add the letter here with a new translation, as Jay's was not complete and incorrect in several places.

Viro Immortali Hermanno Boërhaave, S.P.D. Theodorus Tronchin

Persolidum annum renum ulcere laborantis, succis tandem quasi sanatae Majalibus, post binos menses recruduit malum. Tuum tunc imploranti auxilium, incidens decoctum aperiensque, unà cum ejusdem indolis Pilulis antipuicis, benignus praescripsisti: His quae religiose usa est iterum vides aegram, ad Te medicinae parentem iterum redeuntem, at bene gnaram omnia quae Tibi resistunt incurabilia esse mala. Huic des animam rogat maritus. Valeas, Vir Summe, Vivasque.

$$
\text { Amstelodami } 17 \frac{5}{12} 36 \text {. }
$$

The immortal man, Herman Boerhaave is treeted by Theodore Tronchin

The disease of the woman who suffered all the year long from an ulcus in the kidneys, but who yet seemed to be cured at last through Mayalia juices, has flared up again after two months. When she then called in your help, you kindly prescribed her an incisive and aperient decoction, at once with antisuppuration pills. Now you see her, who faithfully took the remedies, returning to you, obedient to the healing art, though knowing well that all maladies that resist you are incurable. The husband begs that you give her courage. Farewell, superior man, all the best with you.

Amsterdam 5-12-1736. 
«Claro, Nobilique, Viro

Theodoro Tronchino, medico,

HBoerhaave.

Et priorem intentus relegi, et ultimam simul ea sedulo recensens, quae rescripsi: neque tamen vel ita demum excogitare queo causam, quae tamdiu, adeo rebellis ad omnia, vel efficacia satis remedia, exacerbationem finiens nausea, \& vomitu, nisi fixi quid haeserit visceribus: quod recrudescens urget, donec acre virus vi expulerit, excusseritque regeneranti fomiti.

Quum vero nullum in abdomine viscus crebrius tali tragoediae scenas aperit, quam ingens illa, \& scirrhoidi malignitati suscipiendae mire apta, glandula, suspicatus fui, forte $\&$ hic virulenti quid haud ita dissimilis. Sed ambiguum id Tibi rectius judicanti, praesens quippe, imo $\&$ familiaris, es medicus, liberrime cedo. Interim, si quid scio, dolorum diuturnitate ipsa intolerabilium in ventre, causae ad calculos, inflammationem, distentiones nervorum, aut erodens acre, referuntur $a b o b$ servatoribus, probante incisione cadaverum.

Ex quibus virus exurens hic latere unice censetur, quod respondeat omnibus, quae recensentur in historia, malis. an malles mordacis vermis irritamenta causam tanti habere mali? Sit autem alterutrum, est tamen, ut in dubia causa certo uti possimus auxilio, quippe ad utramvis apposite. bibat, vacuo ventriculo,
To the renowned eminent physician

Theodore Tronchin.

From H. Boerhaave, Greeting.

I have read intently your first and last letter, and at the same time I have diligently reconsidered what I had answered. Yet, in this manner, I have not succeeded to ascertain the cause (of the disease) which has been rebellious to all, even satisfactorily efficacious drugs for such a long time, and eventually resulted in an exacerbation with nausea and vomiting-unless it be that something solid has adhered to the entrails. When this bursts again, it causes trouble till it has expulsed the sharp virus so that the regenerative substance is rid of it.

As really none of the abdominal viscera is so frequently the scene of such tragedy but the large gland which is so extremely liable to develop scirrhoidal malignity, I suspect that some not very dissimilar virus plays a part. But this is ambiguous, and will gladly leave more correct discrimination to you, being in the patient's presence, nay even being his friend and physician. Meanwhile, if I have a little insight into this, the causes of these abdominal pains, which are unbearable just because of their long duration, are ascribed to stones, inflammation, distension of nerves, or some fretting sharpness by researchers, referring to the proves of cadaver dissections.

The assumption of a hidden, searing virus flowing from (one of) these causes corresponds particularly well to all the symptoms mentioned in the case history. Or would you rather assume that the irritation of a gnawing worm were the cause of so much evil ? Yet, in either case, though the cause be dubious, a sure remedy is possible, because it applies to both. Let the patient, 
hora ante refectionem, drachmam de oleo amygdalino recens presso, cui pauxillum de vitello ovi admistum, \& aequa copia Syrupi de althaea Fernellii. quadrante horae elapso post haec, deglutiat 111 de catapotus $A$ in priore consilio commendatis supersorbens uncias 111 de decocto B ibidem commemorato. Saepe interim infundantur clysteres ex unciis IV olei Lini recentissime pressi commisto simul Syrupo althaeae ad uncias binas. His fiat periculum, si debellari queat atrocia, adve inducias reduci. Vale diu felix.

Leydae $17 \frac{26}{1} 38$. fasting, one hour before breakfast, drink one drachm of recently pressed almond oil, to which equal amounts of yoke of egg and althæa syrup of Fernel are added. A quarter of an hour thereafter he should take three of the pills A recommended in the previous consultation, and drink also three ounces of decoction $B$ mentioned on the same occasion. Meanwhile he should be given frequent enemas of four ounces of newly pressed olive oil, instantly mixed with two ounces of althaea syrup. Give it a trial to see whether so the pain may be abated and stopped. Live long and happily.

Leyden, 26-1-1738.

Obviously when writing Boerhaave's pen was bad, and his punctuation was incomplete. Some of his sentences are in fact difficult to translate.

Writing this letter Boerhaave had already been ill for a few months ${ }^{8}$. He suffered from increasing dyspnoea and dropsy, and showed all signs of heart failure. A few months later he was to make his will. But he kept in contact with Tronchin till the end of his life.

Henri Tronchin published in translation, a passage of a letter from Boerhaave to Tronchin, dated April 91730.

«Je suis malade depuis quatre mois. Le mal a son siège dans les poumons et il est souvent si violent qu'il me cause des suffocations; je me traine, je suis étouffé quand je monte, j'ai septante ans, le corps usé par le travail et je prévois facilement ce qui approche. Ce que Dieu fait est bien, de quelque manière qu'il le fasse. A lui seul la gloire! Adieu!»

Tronchin visited Boerhaave even on his death bed. On February $9^{\text {th }} 1739$, five months after the death of his beloved teacher, he told the story of this moving interview.

«Les larmes me vinrent aux yeux en le quittant, il s'en aperçut, il me prit la main et la serra. Je lui dis que malgré l'arrêt qu'il venait de prononcer contre luimême, j'esperais que le Ciel recevrait nos vœux et se

8 G.A.Lindeвоom, Boerhaaves Krankheiten, Sudhoffs Arch. Gesch. Med. und Nat. 39 (1955) 161-77. Also: Ned. Tijdschrift voor Geneeskunde 99 (1955), 3519. 
rendrait à nos prières; j'ajoutaî : et à celles que toute l'Europe faisait pour son rétablissement. "Vous n'ignorez pas, mon bon ami, me répondit-il, «que l'opinion gouverne le monde. Quand Sylvius de la Boë mourut, on croyait »sa perte irréparable; deux ans après sa mort il était déjà oublié; il en »sera de même de moi et il faut que cela soit ainsi.»

\section{Tronchin successor of Boerhaave?}

So, for ten years, from 1728 to 1738 there was a good understanding between Boerhaave and Tronchin. It is clear that Boerhaave appreciated him as a good practitioner and a gifted physician, and that he held him in great esteem. But did he see something more in him ? Did he consider him to be a possible successor?

Theodore Tronchin's biographer said that, during the last years of his life, Boerhaave tried to persuade him to come to Leiden and take over some of his university duties. It is not clear from which source H. Tronchin derived this information.

But we are well informed about Boerhaave's opinion on how his chair should be filled after his death. For, the Curators (Gouvernors of the University) asked for Boerhaave's own advice on this. Their Secretary called on the hopelessly diseased professor on April $22^{\text {nd }}, 1738$. A detailed record of this interview is left ${ }^{9}$. On this occasion Boerhaave advised to divide his duties among four men, Oosterdyk Schacht, Van Royen, Albinus and Gaubius. At the end of this interview Boerhaave let his thoughts for a little while dwell on Germany, whether there were some outstanding physician who might be a candidate, and then, by the way, he also mentioned Tronchin, "that he had an excellent disciple too, who was called Tronchin, but that he had devoted himself entirely to his practice at Amsterdam, and that he was engorged by it, but as for his succes in teaching he again could not affirm".

Thus, this is Boerhaave's conclusion on Tronchin. He deemed him an outstanding and talented disciple, but fully occupied by practice, and about whose gift for teaching he was not certain.

\section{Tronchin's Homage to Boerhaave}

It is true, Tronchin was to be a professor of medicine in Geneva, from 1754 to 1766 . In his inaugural oration, disinterred from the family re-

9 SiegenbeeK, Geschiedenis der Leidsche Hoogeschool, Leiden 1832, II, p. 397. 
cords by GoLDSCHMID ${ }^{10}$, he paid homage to his former teacher in high-flown worlds,

"However, be it permitted to inscribe in the temple the name of one, æqual to Hippocrate: Boerhaave, who, rich by the medical inventions of all centuries, very experienced in chemistry, botany, anatomy and mechanics, full of the learning of the erudition of the ancients, has formed a system of medicine, which will be spared by the voracious tooth of time.

Neverthless his fate will be the same as that of Hippocrate, and the same obstacles will thwart him.

Unfortunately the errors of doctors, their laziness, their vanity, make and will ever make this work too heavy for their feeble hands. There are less rugged paths along which one can walk without having a firm step and a sinewy calf. And thus it is that medicine, it is sad to say, is likely to remain as it always has been the scourge of the human race.

It was a prophesy of the dying Boerhaave; I have carried with me these words deeply in my heart; if they could have been dashed off by tears, they would have been vanished from my memory already long time."

\section{Conclusion}

The circumstances in which Tronchin was to fulfill his professorship did not favour the full development of his teaching abilities. It caused a lot of trouble to get a suitable lecture room; there were but a few medical students, though he did draw a large non-medical audience; there was no hospital at his disposal, and his extensive practice did not leave him much time to attend to scientific studies. Moreover, he excelled in practice rather than in theory of medicine. As a hygienist he was far ahead of the period. The tremendous celebrity he later gained at Paris proves that there he found his proper sphere ${ }^{11}$. Regarding his distinguished and international clientele Voltaire rightly calls him "successeur du grand Boerhaave", though he did not succeed to his chair. In fact, Tronchin did not establish his name and renown by teaching medicine, he did so by inoculating royalties.

To us it seems that the subsequent life and development of Tronchin shows that the cautious statement of old dying Boerhaave, the "praeceptor communis Europae", was right after all.

10 E. Goldschmid, Theodore Tronchin. Atti deli VIII ${ }^{\circ}$ Congresso internaz. di storia della medicina 1930, p. 301. Pisa 1931.

11 G.A.Lindeвоoм, Theodore Tronchin, Ned. T. v. Geneeskunde 100 (1956) 1999. 